\title{
Penggunaan Error Correction Mechanism Dalam Analisis Pengaruh Investasi Langsung Luar Negeri Terhadap Pertumbuhan Ekonomi Indonesia
}

\author{
SATRIA JUNE ADWENDI, FITRI KARTIASIH \\ Sekolah Tinggi Ilmu Statistik (STIS) \\ Jl. Otista No. 64C, Jakarta \\ 11.6897@stis.ac.id \\ fkartiasih@stis.ac.id
}

\begin{abstract}
ABSTRAK
A developing country like Indonesia would require funds to increase their economic performance. The contribution of savings are not enough to finance national development. It is necessary to find other financial resources which is foreign direct investment. Error Correction Mechanism (ECM) is used to analyze the influence of foreign direct investment and other interconnected sectors in open economy like domestic credit, government spending, and inflation to economic growth. The result shows that domestic credit, government spending, and inflation increase, but government spending and foreign direct investment tends to be fluctuating from 2000-2014. The research results also showed that economic growth in the long term is influenced by domestic credit and inflation, while in the short term are influenced by foreign direct investment and domestic credit.
\end{abstract}

Keywords: investment, FDI, economic growth, credit, ECM

\section{PENDAHULUAN}

Dalam membangun perekonomiannya, negara berkembang seperti Indonesia tentunya akan membutuhkan dana yang tidak sedikit. Sumber pendanaan yang akan digunakan dapat berasal dari tabungan domestik. Akan tetapi pada umumnya kontribusi tabungan tidak cukup untuk membiayai pembangunan nasional. Untuk itu dibutuhkan sumber pembiayaan lain yang lebih banyak diambil dari pinjaman luar negeri dan investasi langsung luar negeri (Foreign Direct Investment-FDI).

Pemerintah Indonesia mengadakan International Infrastructure Summit pada tanggal 17 Januari 2005 dan BUMN Summit pada tanggal 25-26 Januari 2005. Infrastructure Summit dan BUMN Summit membuat investor asing lebih bebas dalam penanaman modal. Dalam Summit tersebut pemerintah menyatakan tidak akan ada perbedaan perlakuan terhadap bisnis Indonesia ataupun bisnis asing yang beroperasi di Indonesia. Dua tahun setelahnya perlakuan yang sama tersebut tidak hanya pada bagian infrastruktur atau BUMN saja, tetapi pada seluruh perusahaan asing. Pemerintah mengeluarkan Undang-Undang No 25 Tahun 2007 tentang penanaman modal asing yang menyatakan pemerintah memberikan perlakukan yang sama kepada seluruh penanam modal baik dari Indonesia maupun asing.

Sejak tahun 2010 investasi langsung luar negeri yang masuk ke Indonesia menunjukkan peningkatan pesat. Indonesia mulai masuk menjadi target penanaman modal yang menjanjikan bagi perusahaan-perusahaan asing. Pemicunya adalah ketika Indonesia mampu menghadapi krisis global tahun 2008-2009 dengan mencatatkan pertumbuhan positif 4,5 persen pada tahun 2009. Nilai pertumbuhan ini tertinggi ketiga di dunia setelah China dan India (BI, 2009).

Namun keberadaan investasi langsung luar negeri tidak selalu menguntungkan perekonomian bagi negara penerimanya karena dapat menurunkan tingkat tabungan maupun investasi domestik sehingga tercipta berbagai bentuk persaingan yang tidak sehat yang bersumber dari 
perjanjian-perjanjian antara pihak investor dan pemerintah. Memperluas masuknya investasi asing belum berarti akan menjamin peningkatan devisa. Ini disebabkan nilai keuntungan investasi asing yang direpatriasi dari negara-negara berkembang pada umumnya melebihi nilai dana investasi asing yang masuk ke negara-negara ini. Dalam jangka pendek investasi langsung luar negeri dapat memperbaiki posisi penerimaan negara, namun dalam jangka panjang dampaknya justru negatif karena adanya pengiriman kembali keuntungan, hasil bunga, royalti, dan dana-dana lainnya ke negara asalnya.

Dampak jangka pendek dan jangka panjang dari investasi langsung luar negeri perlu diteliti karena Indonesia sebagai negara berkembang masih sangat bergantung pada dana dari luar negeri. Selain variabel investasi langsung luar negeri dalam penelitian ini variabel lain yang muncul dari perekonomian empat sektor dan diduga berpengaruh terhadap pertumbuhan ekonomi yaitu kredit domestik, pengeluaran pemerintah, dan inflasi. Penelitian ini berupa amatan waktu dari tahun 2000 sampai dengan tahun 2014. Periode penelitian dimulai tahun 2000 karena pada periode inilah perekonomian Indonesia mulai stabil pasca krisis moneter 1997-1998.

Dari uraian diatas maka diperoleh rumusan masalah sebagai berikut:

1. Bagaimana perkembangan pertumbuhan ekonomi, investasi langsung luar negeri, kredit domestik, pengeluaran pemerintah, dan inflasi di Indonesia?

2. Bagaimana pengaruh investasi langsung luar negeri, pengeluaran pemerintah, kredit domestik dan inflasi terhadap pertumbuhan ekonomi Indonesia?

\section{LANDASAN TEORI}

\section{Pendapatan Per Kapita}

Salah satu komponen dari pendapatan nasional yang selalu dilakukan perhitungannya adalah pendapatan perkapita, yaitu pendapatan rata-rata penduduk suatunegara pada suatu masa tertentu. Nilainya diperoleh dengan membagi nilai Produk Domestik Bruto atau Produk Nasional Bruto dengan jumlah penduduk pada tahun tersebut (Sukirno, 2004).

Dengan demikian pendapatan perkapita dapat dihitung dengan formula:

$$
\text { PDB Per kapita }=\frac{\text { PDB }}{\text { Jumlah Penduduk }}
$$

\section{Pertumbuhan Ekonomi}

Boediono (1989), mendefinisikan pertumbuhan ekonomi sebagai suatu proses kenaikan output per kapita jangka panjang yang terjadi apabila ada kecenderungan output per kapita naik yang bersumber dari kekuatan yang berada dalam perekonomian itu sendiri, bukan berasal dari luar atau bersifat sementara atau dengan kata lain self generating. Self generating dapat diartikan bahwa proses pertumbuhan itu sendiri menghasilkan suatu kekuatan atau momentum bagi kelanjutan pertumbuhan tersebut dalam periode-periode selanjutnya.

Pertumbuhan ekonomi adalah perkembangan kegiatan ekonomi dari waktu ke waktu dan menyebabkan pendapatan nasional riil berubah. Tingkat pertumbuhan ekonomi menunjukkan persentase kenaikan pendapatan nasional riil pada suatu tahun tertentu dibandingkan dengan pendapatan nasional riil pada tahun sebelumnya (Sukirno, 2004).

\section{Model Pertumbuhan Harrod-Domar}

Dalam model pertumbuhan Harrod-Domar dijelaskan bahwa untuk memacu pertumbuhan ekonomi dibutuhkan investasi baru yang merupakan tambahan netto terhadap cadangan atau stok modal (capital stock). Dengan asumsi ada hubungan ekonomi langsung antara besarnya stok modal secara keseluruhan (K) terhadap GNP (Y) yang dikenal sebagai rasio modal-output (capital-output rasi) (Todaro dan Smith, 2003). 
Misalkan rasio modal-output sebagai $\mathrm{k}$ dan rasio tabungan nasional (national saving ratio) sebagai s maka dapat disusun model pertumbuhan ekonomi Harrod- Domar yang sederhana.

$$
\frac{\Delta \mathrm{Y}}{\mathrm{Y}}=\frac{\mathrm{s}}{\mathrm{k}}
$$

Bahwa tingkat pertumbuhan GNP $(\Delta Y / Y)$ ditentukan secara bersama-sama oleh rasio tabungan nasional (s) serta rasio modal-output nasional (k). Secara spesifik bahwa tingkat pertumbuhan pendapatan nasional secara langsung berbanding lurus dengan rasio tabungan dan berbanding terbalik dengan rasio modal-output.

\section{Model Pertumbuhan Neoklasik Solow}

Model pertumbuhan Solow merupakan pengembangan dari model pertumbuhan HarrodDomar dengan menambahkan faktor kedua, yakni tenaga kerja dan memperkenalkan variabel independen ketiga, yakni teknologi kedalam persamaan pertumbuhan. Dalam model pertumbuhan Solow, input tenaga kerja dan modal memakai asumsi skala yang terus berkurang (diminishing returns) jika keduanya dianalisis secara terpisah, sedangkan jika keduanya dianalisis secara bersamaan memakai asumsi skala hasil tetap (constant returns to scale) (Todaro dan Smith, 2003).

Model pertumbuhan Neoklasik Solow dinyatakan dalam persamaan :

$$
\mathrm{Y}=\mathrm{K}^{\mathrm{a}}(\mathrm{AL})^{1-\mathrm{a}}
$$

dimana:

Y : Produk domestik bruto (PDB)

$\mathrm{K}$ : Stok modal fisik dan modal manusia

L : Tenaga kerja

A : Tingkat kemajuan teknologi

a : Elastisitas output terhadap modal (persentase kenaikan PDB yang bersumber dari 1 persen penambahan modal fisik dan modal manusia.

\section{Investasi}

Investasi, yang lazim disebut juga dengan istilah penanaman modal atau pembentukan modal merupakan komponen kedua yang menentukan tingkat pengeluaran agregat (Sukirno 2004). Menurut Undang-Undang Republik Indonesia Nomor 25 Tahun 2007, Penanaman modal adalah segala bentuk kegiatan menanam modal, baik oleh penanam modal dalam negeri maupun penanam modal asing untuk melakukan usaha di wilayah negara Republik Indonesia.

Istilah investasi dapat diartikan sebagai pengeluaran atau pengeluaran penanam-penanam modal atau perusahaan untuk membeli barang-barang modal dan perlengkapan-perlengkapan produksi untuk menambah kemampuan memproduksi barang-barang dan jasa-jasa yang tersedia dalam perekonomian. Pertambahan jumlah barang modal ini memungkinkan perekonomian tersebut menghasilkan lebih banyak barang dan jasa di masa yang akan datang. Adakalanya penanaman modal dilakukan untuk menggantikan barang-barang modal yang lama yang telah haus dan perlu didepresiasikan (Sukirno, 2004).

\section{Investasi langsung luar negeri}

Todaro dan Smith (2003), mendefinisikan investasi langsung luar negeri sebagai suatu investasi yang dana-dananya langsung digunakan untuk menjalankan kegiatan bisnis atau mengadakan alat-alat atau fasilitas produksi seperti membeli lahan, membuka pabrik-pabrik, mendatangkan mesin-mesin, membeli bahan baku dan sebagainya.

Investasi langsung luar negeri atau Penanaman modal asing menurut Undang-Undang Republik Indonesia Nomor 25 Tahun 2007, adalah kegiatan menanam modal untuk melakukan 
usaha di wilayah negara Republik Indonesia yang dilakukan oleh penanam modal asing, baik yang menggunakan modal asing sepenuhnya maupun yang berpatungan dengan penanam modal dalam negeri. Penanam modal asing adalah perseorangan warga negara asing, badan usaha asing, dan/atau pemerintah asing yang melakukan penanaman modal di wilayah negara Republik Indonesia.

Peranan investasi luar negeri dalam perekonomian atau pertumbuhan ekonomi sampai saat ini masih diperdebatkan, baik mengenai intensitas maupun arahnya. Menurut Todaro dan Smith (2003), terdapat dua kelompok pandangan mengenai investasi luar negeri. Kelompok pertama adalah kelompok yang mendukung investasi luar negeri, mereka memandang investasi luar negeri sebagai pengisi kesenjangan antara persediaan tabungan, cadangan devisa, penerimaan pemerintah, dan keahlian manajerial yang terdapat di negara penerimanya dengan tingkat persediaan yang dibutuhkan untuk dapat mencapai target-target pertumbuhan dan pembangunan. Kelompok kedua adalah kelompok yang menentang investasi luar negeri dengan perusahaan multinasionalnya, mereka berargumen bahwa investasi luar negeri cenderung menurunkan tingkat tabungan dan investasi domestik sehubungan dengan terciptanya persaingan yang tidak sehat yang bersumber dari perjanjian produksi antara pihak perusahaan multinasional dengan pihak pemerintah di negara tuan rumah, dalam jangka panjang penanaman modal asing dapat mengurangi penghasilan devisa karena adanya impor besarbesaran atas barang setengah jadi dan barang modal dari perusahaan multinasional serta dikarenakan adanya pengiriman kembali keuntungan, hasil bunga, royalti, biaya-biaya jasa manajemen, dan dana-dana lainnya ke negara asalnya.

\section{Kredit}

Berdasarkan Undang-Undang Republik Indonesia Nomor 10 Tahun 1998, kredit adalah penyediaan uang atau tagihan yang dapat dipersamakan dengan itu, berdasarkan persetujuan atau kesepakatan pinjam-meminjam antara bank dengan pihak lain yang mewajibkan pihak peminjam untuk melunasi utangnya setelah jangka waktu tertentu dengan pemberian bunga.

\section{Pengeluaran Pemerintah}

Pemerintah bukan saja berfungsi untuk mengatur kegiatan perekonomian tetapi juga dapat mempengaruhi tingkat pengeluaran agrergat dalam perekonomian (Sukirno, 2004). Menurut Badan Pusat Statistik pengeluaran konsumsi pemerintah sama dengan produksi pemerintah yang dikonsumsi sendiri, yaitu produksi bruto pemerintah dikurangi penerimaan dari produksi berupa barang dan jasa yang dihasilkan.

\section{Inflasi}

Menurut Badan Pusat Statistik, inflasi adalah persentase tingkat kenaikan harga sejumlah barang dan jasa yang secara umum dikonsumsi rumah tangga.

Rumus mendapat nilai inflasi :

$$
\begin{gathered}
\mathrm{IHK}=\frac{\sum_{\mathrm{i}=1}^{\mathrm{k}} \frac{\mathrm{P}_{\mathrm{ni}}}{\mathrm{P}_{(\mathrm{n}-1) \mathrm{i}} \mathrm{P}_{(\mathrm{n}-1) \mathrm{i}} \mathrm{Q}_{0 \mathrm{i}}}}{\sum_{\mathrm{i}=1}^{\mathrm{k}} \mathrm{P}_{0 \mathrm{i}} \mathrm{Q}_{0 \mathrm{i}}} \\
\text { Inflasin }_{\mathrm{n}}=\frac{\mathrm{IHK}_{\mathrm{n}} \times \mathrm{IHK}_{\mathrm{n}-1}}{\mathrm{NK}_{\mathrm{n}-1}} \times 100
\end{gathered}
$$

dengan: 


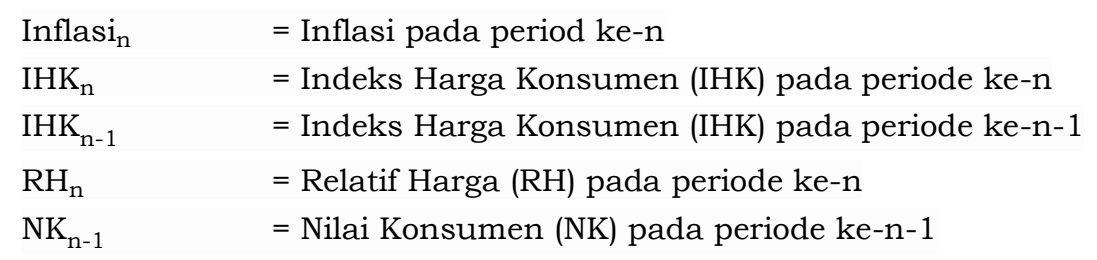

Indeks Harga konsumen (consumer price indeks, CPI) adalah ukuran keseluruhan biaya yang harus dibayarkan oleh seorang konsumen guna memperoleh berbagai barang dan jasa untuk memenuhi kebutuhan hidupnya (Mankiw 2003).

Menurut Badan Pusat Statistik, Indeks Harga Konsumen (IHK) atau biasa disebut juga Consumer Price Index (ICP) secara sederhana merupakan perbandingan antara harga suatu paket komoditas dari suatu kelompok barang atau jasa (market basket) pada suatu periode tertentu terhadap harganya pada periode waktu yang telah ditentukan (tahun dasar). Jadi IHK/CPI ini mengubah harga berbagai barang dan jasa menjadi sebuah indek tunggal yang mengukur seluruh tingkat harga.

\section{Error Correction Mechanism (ECM)}

Model Error Correction Mechanism (ECM) merupakan salah satu analisis time series yang diperkenalkan oleh Sargan dan dikembangkan oleh Engle dan Granger untuk mengoreksi ketidakseimbangan (Gujarati, 2003).

Konsep penting dalam ECM adalah keseimbangan jangka panjang dari data time series yang sering disebut kointegrasi. Dengan demikian dapat dikatakan bahwa ECM merupakan kelanjutan dari pengujian dari kointegrasi yang bertujuan untuk mengoreksi penyimpangan terhadap keseimbangan jangka panjang. Dalam ECM, hubungan dinamis jangka pendek antar variabel dalam sistem dipengaruhi oleh deviasi/ penyimpangan dari keseimbangan jangka panjang (Enders, 2004). Gujarati (2003) juga menjelaskan hal yang sama yaitu, teorema penting yang dikenal sebagai granger representation theorem, menyatakan bahwa jika dua variabel Y dan X berkointegrasi, maka hubungan antara kedua dapat dinyatakan sebagai ECM.

Menurut Engle dan Granger (1987), secara ekonomi, adanya kointegrasi menunjukkan adanya keseimbangan hubungan jangka panjang (long run equilibrium relationship) antara variabel. Namun demikian, walaupun terdapat keseimbangan jangka panjang, dalam jangka pendek mungkin saja hubungan antara variabel tidak mencapai keseimbangan. Dengan kata lain, dalam jangka pendek apa yang diinginkan pelaku ekonomi (desired) belum tentu sama dengan apa yang terjadi sebenarnya. Karena adanya perbedaan apa yang diinginkan dan apa yang terjadi maka diperlukan adanya penyesuaian (adjustment).

Hal penting untuk dicatat adalah bahwa representasi ECM mengharuskan bahwa dua variabel akan berkointegrasi pada order CI $(1,1)$ (Enders, 2004). Namun Enders lebih lanjut menjelaskan bahwa mungkin mendapatkan kointegrasi pada order yang lebih tinggi. Misalnya, satu set I (2) variabel dapat berkointegrasi order CI $(2,1)$ sehingga terdapat kombinasi linier yang I (1).

Dalam jangka pendek, bila pada suatu periode tedapat ketidakseimbangan, maka pada periode berikutnya dalam rentang waktu tertentu akan terjadi proses koreksi kesalahan sehingga kembali pada posisi keseimbangan. Proses koreksi kesalahan ini dapat diartikan sebagai penyelaras (adjustment) perilaku jangka pendek yang berpotensi mengalami ketidakseimbangan ke arah perilaku jangka panjang yang merepresentasikan kondisi keseimbangan.

ECM diterapkan dalam analisis ekonometrika untuk data runtun waktu karena kemampuannya dalam meliput banyak peubah untuk menganalisis fenomena ekonomi jangka panjang dan jangka pendek, serta dalam usaha mencari pemecahan terhadap persoalan peubah runtun waktu yang tidak stasioner dan spurious regression dalam analisis ekonometrika. 


\section{Satria June Adwendi, Fitri Kartiasih}

\section{METODOLOGI}

\section{Data}

Penelitian ini menggunakan data triwulanan dengan periode waktu tahun 2000 kuartal I hingga 2014 kuartal IV dengan ruang lingkup nasional (Indonesia). Penelitian ini ingin melihat pengaruh investasi langsung luar negeri, kredit domestik, pengeluaran pemerintah dan inflasi terhadap pertumbuhan ekonomi Indonesia. Untuk mengetahui pengaruh tersebut, variabel tidak bebas yang digunakan adalah PDB perkapita dan variabel bebas terdiri atas total Penanaman Modal Asing (PMA), nilai kredit rupiah, pengeluaran konsumsi pemerintah dan indeks harga konsumen.

\section{Analisis Infrensia Menggunakan Error Corection Mechanism}

1. Pengujian asumsi stationeritas masing-masing variabel.

Pengujian asumsi stasioneritas pada masing-masing variabel yang digunakan dalam penelitian perlu dilakukan, karena biasanya data-data time series menyimpan masalah autokorelasi yang menyebabkan data menjadi tidak stasioner (mengandung akar unit). Oleh karena itu, dalam membentuk model ekonometrika dari data time series diharuskan menggunakan data yang stasioner. Pengujian stasioneritas dalam penelitian ini menggunakan uji Phillip Peron (PP). Pengujian dilakukan pada semua variabel yaitu PDB perkapita, PMA, kredit domestik, konsumsi pemerintah dan IHK. Pengujian dilakukan dengan menggunakan bantuan program Eviews 8.0 dengan taraf uji sebesar 5 persen. Jika seluruh variabel semuanya tidak stasioner dalam level, maka lanjut ke tahap selanjutnya. Namun, jika ada salah satu variabel yang stasioner pada level maka gunakan model lain.

2. Uji stasioneritas pada ordo yang lebih tinggi untuk semua variabel.

Jika seluruh variabel stasioner pada ordo / difference yang sama, maka lanjut ke tahap selanjutnya. Jika tidak stasioner pada ordo / difference yang sama, gunakan model lain.

3. Melakukan pengujian kointegrasi.

Pengujian ini dilakukan dengan meregresikan seluruh variabel yang tidak stasioner di level, sehingga diperoleh model regresi sebagai berikut :

PDBperkapita

$$
=\beta_{0}+\beta_{1} \text { LNPMA }_{t}+\beta_{2} \text { Kredit }_{t}+\beta_{3} G_{t}+\beta_{4} \text { IHK }_{t}+\varepsilon_{t}
$$

Keterangan :

PDBperkapita $_{t}$ : produk domestik bruto periode ke-t

LNPMA $_{\mathrm{t}} \quad$ : logaritma natural investasi langsung luar negeri periode

Kredit $_{\mathrm{t}} \quad:$ kredit domestik periode ke- $\mathrm{t}$

$\mathrm{G}_{\mathrm{t}} \quad:$ pengeluaran pemerintah periode ke- $\mathrm{t}$

$\mathrm{IHK}_{\mathrm{t}} \quad$ : indeks harga konsumen periode ke-t

$\beta_{0} \quad:$ konstanta

$\beta_{1}, \beta_{2}, \beta_{3}, \beta_{4} \quad$ : parameter kointegrasi

$\mathrm{t} \quad$ : waktu

$\varepsilon_{\mathrm{t}} \quad:$ error persamaan jangka panjang

Sehingga diperoleh residual dari model adalah sebagai berikut :

$$
\varepsilon_{t}=\text { PDBperkapita }_{t}-\beta_{0}-\beta_{1} \text { LNPMA }_{t}-\beta_{2} \text { Kredit }_{t}-\beta_{3} G_{t}-\beta_{4} I_{t}
$$


4. Uji stasioneritas dari residual.

Jika residual stasioner ketika dilakukan uji unit root, maka dikatakan seluruh variabel terkointegrasi . Berarti terdapat hubungan jangka panjang di antara variabel-variabel tersebut, dan lanjut ke tahap selanjutnya. Jika residual tidak stasioner, maka gunakan model lain.

5. Regresikan seluruh variabel yang telah stasioner pada ordo yang sama dengan menambahkan lag pertama residual persamaan kointegrasi.

Model ECM dapat digunakan apabila seluruh variabel yang tidak stasioner pada level memiliki kointegrasi. Apabila ternyata hasil pengujian kointegrasi diperoleh bahwa terdapat kointegrasi variabel-variabel penelitian, langkah selanjutnya adalah memasukkan lag pertama residual persamaan kointegrasi dalam meregresikan variabel yang telah stasioner. Maka, model ECM yang terbentuk dapat dituliskan sebagai berikut :

$$
\Delta \text { PDBperkapita }{ }_{\mathrm{t}}=\mathrm{a}_{0}+\mathrm{a}_{1} \Delta \mathrm{LNPMA}_{\mathrm{t}}+\mathrm{a}_{2} \Delta \text { Kredit }_{\mathrm{t}}+\mathrm{a}_{3} \Delta \mathrm{G}_{\mathrm{t}}+\mathrm{a}_{4} \Delta \mathrm{IHK}_{\mathrm{t}}+\gamma \varepsilon_{\mathrm{t}-1}+\mathrm{u}_{\mathrm{t}}
$$

Keterangan :

$\triangle$ PDBperkapita $_{\mathrm{t}}$ : perubahan produk domestik bruto periode ke-t

$\triangle \mathrm{LNPMA}_{\mathrm{t}} \quad$ : perubahan logaritma natural investasi langsung luar negeri periode ke-t

$\Delta$ Kredit $_{\mathrm{t}} \quad$ : perubahan kredit domestik periode ke-t

$\Delta \mathrm{G}_{\mathrm{t}} \quad:$ perubahan pengeluaran pemerintah periode ke-t

$\Delta \mathrm{IHK}_{\mathrm{t}} \quad:$ perubahan indeks harga konsumen periode ke- $\mathrm{t}$

$\mathrm{a}_{0} \quad$ : konstanta

$\mathrm{a}_{1}, \mathrm{a}_{2}, \mathrm{a}_{3}, \mathrm{a}_{4} \quad$ : parameter jangka pendek

$\gamma \quad$ : speed of adjusment

$\varepsilon_{\mathrm{t}-1} \quad:$ Error Correction Term (ECT)

$\mathrm{t} \quad:$ waktu

$\mathrm{u}_{\mathrm{t}} \quad$ : error persamaan jangka pendek

Periksa speed of adjustment-nya (koefisien dari lag pertama residual). Nilai koefisien tersebut harus betanda negatif .Jika hasilnya bertanda positif, model ECM tersebut tidak bisa digunakan karena akan menghasilkan regresi yang palsu (spurious).

6. Pengujian asumsi klasik

Setelah diperoleh model estimasi Error Correction Mechhanism (ECM), selanjutnya dilakukan pengujian asumsi klasik yang dilakukan dengan bantuan program Eviews 8.0. Pengujian asumsi klasik normalitas dilakukan dengan uji Jarque-Berra (JB). Kemudian pengujian asumsi nonmultikolonieritas dilakukan dengan melihat nilai VIF setiap variable yang tidak lebih dari 10. Selanjutnya pengujian asumsi klasik nonautokorelasi dilakukan dengan uji Lagrange Multiplier (LM). Pengujian dilanjutkan dengan asumsi klasik homoskedastik yang dilakukan dengan menggunakan uji white.

7. Pengujian keberartian model. Pengujian ini dilakukan dengan melihat nilai koefisien determinasi yang disesuaikan ( $\mathrm{R}^{2}$ adjusted), uji simultan,dan uji parsial. Uji simultan dilakukan untuk mengetahui apakah semua variabel penjelas (investasi langsung luar negeri, kredit domestik, pengeluara pemerintah, dan indeks harga konsumen) secara bersama-sama memengaruhi PDB perkapita di Indonesia. Uji parsial dilakukan untuk mengetahui pengaruh masing-masing variabel (investasi langsung luar negeri, kredit domestik, pengeluaran pemerintah, dan indeks harga konsumen) secara parsial terhadap PDB perkapita di Indonesia. 


\section{HASIL DAN PEMBAHASAN}

\section{Gambaran Umum PDB Perkapita, Investasi , Kredit Domestik, Pengeluaran Pemerintah dan Indeks Harga Konsumen Periode 2000-2014}

Produk domestik bruto perkapita atau PDB perkapita merupakan salah satu tolok ukur dalam melihat pertumbuhan ekonomi. PDB perkapita Indonesia periode 2000-2014 cukup bagus dan memiliki trend positif. PDB perkapita terendah terjadi pada kuartal pertama tahun 2000 yaitu sebesar Rp1.665.596,59. Nilai ini terus meningkat hingga nilai tertinggi terjadi pada kuartal ketiga tahun 2014 yaitu sebesar Rp2.968.514,143. Sedangkan pada kuartal keempat 2014 nilai PDB perkapita turun dibanding kuartal sebelumnya, nilai ini turun sebanyak Rp50.688,94 sehingga menjadi RP2.968.514,12

Investasi langsung atau penanaman modal di Indonesia dibagi menjadi dua yaitu penanaman modal asing (PMA) dan penanaman modal dalam negeri (PMDN). Dalam penelitian ini menggunakan data PMA dan PMDN yang sudah direalisasikan. perkembang investasi atau penanaman modal di Indonesia terus meningkat sejak tahun 2000 sampai tahun 2014. Penanaman modal di Indonesia kuartal pertama tahun 2000 sebesar 17,9654 triliun rupiah, dimana nilai ini terdiri atas PMA sebesar 10,2546 trilun rupiah dan PMDN sebesar 7,710. Pada tahun 2014 nilai penanaman modal Indonesia sebesar 120,4487 triliun rupiah, dimana nilai ini terdiri dari PMA sebesar 78,7 triliun rupiah dan PMDN sebesar 41,774 triliun rupiah. Penanaman modal Indonesia pada periode 2000 sampai 2014 selalu lebih besar PMA daripada PMDN. Pada kuartal pertama tahun 2000 nilai PMA 1,329 kali lebih besar dariada PMDN. Pada kuartal keempat tahun 2014 nilai PMA 1,885 kali lebih besar daripada PMDN.

Kredit domestik memiliki trend positif dan stabil setiap kuartalnya. Setiap peningkatan yang terjadi cenderung sama setiap kuartalnya dan tidak pernah mengalami penurunan sekalipun sehingga gambar garis yang dihasilkan dari data kredit domestik berbentuk garis yang mulus tidak terdapat patahan-patahan.

Pengeluaran konsumsi pemerintah trend data yang meningkat. Pada tahun 2000 sampai 2004 perubahan nilai cenderung stabil. Namun sejak tahun 2005 sampai 2014 cenderung berfluktuatif dan membentuk pola setiap tahunnya. Pengeluaran konsumsi pemerintah sejak tahun 2005 memiliki nilai kuartal pertama selalu jauh lebih kecil dibandingkan dengan kuarta ketiga dan keempat tahun sebelumnya, namun tetap lebih besar dibandingkan kuartal pertama tahun sebelumnya.

Indeks harga konsumen selalu meningkat setiap triwulan. Pada kuartal kedua tahun 2009 nilai indeks harga konsumen mengalami penurunan dari kuartal sebelumnya. Nilai pada kuartal kedua 2009 sebesar 219,25 turun sebesar -0,359 dari kuartal pertama tahun 2009. Penurunan nilai ini adalah satu-satunya sepanjang periode 2000 sampai 20014, selain kuartal tersebut nilai indeks harga konsumen selalu meningkat dibandingkan kuartal sebelumnya.

\section{Pengaruh Penanaman Modal Asing, Kredit Domestik, Pengeluaran Konsumsi Pemerintah dan Indeks Harga Konsumen Terhadap PDB perkapita Indonesia Periode 2000-2014}

Setelah melalui tahapan pembentukan model (lampiran 3) didapatkan persamaan jangka panjang dan persamaan jangka pendek sebagai berikut:

Persamaan Jangka Panjang:

$$
\begin{aligned}
\text { PDBperkapita }_{t}= & 1.084 .311^{*}+15.272,46 \text { LNPMA }_{t}+0,17363 \text { Kredit }_{t}{ }^{*} \\
& -0,933755 G_{t}+4.352,2 I H K_{t}{ }^{*}
\end{aligned}
$$

Persamaan Jangka Pendek:

$$
\begin{aligned}
& \text { DPDBperkapita } \\
& -1.099,00+15.546,55 \text { DLNPMA }_{t}{ }^{*}+0,44909 \text { DKredit }_{t}{ }^{*}- \\
& 0,656403 D G_{t}+13,6089 D I H K_{t}-0,873974 \varepsilon_{t-1}{ }^{*}
\end{aligned}
$$

* signifikan pada alfa $5 \%$

Pada persamaan jangka panjang didapatkan nilai konstanta 1.084.311 . Nilai tersebut signifikan pada alfa 5\%, yang artinya dengan tingkat kepercayaan 95\% dapat dikatakan nilai PDB perkapita tahun $\mathrm{t}$ bernilai Rp1.084.311 dengan asumsi variabel lain tetap atau ceteris 
paribus. Pada persamaan jangka pendek didapatkan nilai konstanta $-1.099,00$ namun tidak signifikan secara statistik.

Koefisien PMA pada persamaan jangka panjang sebesar 15.272,46 namun tidak berpengaruh signifikan secara statistik. Koefisien PMA pada persamaan jangka pendek bernilai $15.546,55$ dan signifikan secara statistik. Dengan tingkat kepercayaan 95\% dalam jangka pendek dapat dikatakan setiap kenaikan 1\% investasi langsung luar negeri di Indonesia akan menaikan PDB perkapita sebesar Rp15.546,55. Hal paling penting dalam hasil penelitian ini tentang investasi langsung luar negeri adalah nilai positif pada persamaan jangka pendek yang sesuai dengan teori ekonomi bahwa penanaman modal asing berpengaruh postif terhadap pertumbuhan ekonomi. Mengenai koefisien investasi langsung luar negeri pada persamaan jangka panjang yang tidak signifikan juga sesuai dengan salah satu teori yang menyebutkan kerugian penanaman modal asing yaitu berupa adanya pengiriman kembali keuntungan, hasil bunga, royalti, biaya-biaya jasa manajemen, dan dana-dana lainnya ke negara asalnya.

Nilai koefisien kredit domestik pada persamaan jangka panjang sebesar 0,1736 dan signifikan secara statistik. Dengan tingkat kepercayaan 95\% dapat disimpulkan bahwa dalam jangka panjang, setiap kenaikan 1 milyar rupiah kredit domestik mengakibatkan kenaikan PDB perkapita sebesar Rp0,1736. Nilai koefisien kredit domestik pada persamaan jangka pendek sebesar 0,4909 dan signifikan secara statistik. Dengan tingkat kepercayaan 95\% dapat disimpulkan bahwa dalam jangka pendek, setiap kenaikan 1 milyar rupiah kredit domestik mengakibatkan kenaikan PDB perkapita sebesar Rp0,4909. Dari hasil penelitian ini terlihat kredit domestik sangat penting terhadap pertumbuhan ekonomi Indonesia. Baik dalam persamaan jangka panjang maupun jangka pendek kredit domestik berpengaruh positif dan signifikan terhadap PDB perkapita. Hasil ini sesuai dengan teori keuangan dan perekonomian dimanana kredit yang disalurkan bank akan mendorong pertumbuhan ekonomi.

Pengaruh kredit domestik terlihat kecil karena nilai kredit 1 milyar dibandingkan dengan PDB perkapita yang merupakan nilai individu setiap orang seluruh Indonesia. Jika dilihat dari Produk Domestik Bruto, pengaruh kredit cukup besar. Untuk melihat pengaruh kredit domestik terhadap PDB maka koefisien kredit dikalikan dengan jumlah penduduk Indonesia tahun 2014. Pada jangka panjang setiap kenaikan kredit domestik 1 milyar rupiah mengakibatkan kenaikan PDB sebesar Rp42.614.601,24. Pada jangka pendek setiap kenaikan kredit domestik 1 milyar rupiah mengakibatkan kenaikan PDB sebesar Rp110.221.685,61.

Nilai koefisien pengeluaran konsumsi pemerintah pada persamaan jangka panjang -0,9337 dan tidak signifikan secara statistik. Begitu juga dalam persamaan jangka pendek nilai pengeluaran konsumsi pemerintah sebesar -0.6564 dan tidak signifikan secara statistik. Hal ini bisa saja terjadi dikarenakan konsumsi pemerintah sejak 2008 yang tidak stabil dan memiliki pola setiap tahun. Kecenderungan pengeluaran konsumsi pemerintah adalah kecil pada kuartal pertama dan kuartal kedua, lalu besar pada kuartal ketiga dan kuartal keempat. Hal ini mungkin terjadi dikarenakan pada awal tahun anggaran belum cair dan belum direalisasikan sehingga pada akhir tahun anggaran yang masih belum berjalan digunakan semua, sehingga pengeluaran konsumsi pemerintah lebih besar pada kuartal ketiga dan keempat.

Nilai koefisien indeks harga konsumen pada jangka panjang sebesar 4.352,2 dan signifikan secara statistik. Dengan tingkat kepercayaan 95\% dapat disimpulkan bahwa dalam jangka panjang, setiap kenaikan 1 indeks akan menaikan PDB perkapita sebesar Rp4.352,2. Hasil postif dari indeks harga konsumen terhadap PDB perkapita dikarenakan inflasi yang terjadi di masih tergolong inflasi rendah. Sehingga meningkatnya inflasi atau meningkatnya indeks harga konsumen akan memacu pertumbuhan ekonomi Indonesia. Nilai koefisien indeks harga konsumen pada persamaan jangka pendek 13,6089 dan tidak signifikan secara statistik.

Nilai Error Corectin Term -0.8739 dan signifikan secara statistik. Dengan tingkat kepercayaan 95\%, nilai ini menunjukan bahwa sebesar 87,39\% ketidakseimbangan jangka pendek yang terjadi akibat perubahan-perubahan pada PDB perkapita pada periode sebelumnya akan disesuaikan menuju keseimbangan jangka panjang pada periode sekarang. Nilai ini menunjukan dalam waktu singkat sudah mencapai posisi keseimbangan jangka panjang.

\section{KESIMPULAN}

Perkembangan pertumbuhan ekonomi (PDB perkapita), investasi langsung luar negeri, kredit domestik, pengeluaran pemerintah, dan inflasi (indeks harga konsumen) indonesia periode 2000-2014 cenderung mengalami pertumbuhan yang meningkat. Perkembangan investasi langsung luar negeri, dan pengeluaran pemerintah sangat berfluktuatif, sementara untuk 
perkembangan PDB pekapita, kredit domestik, dan indeks harga konsumen tidak terlalu berfluktuasi dan lebih stabil.

Berdasarkan persamaan jangka panjang diperoleh bahwa variabel yang berpengaruh signifikan terhadap pertumbuhan ekonomi adalah kredit domestik dan inflasi. Berdasarkan persamaan jangka pendek atau model ECM diperoleh bahwa variabel yang berpengaruh signifikan terhadap pertumbuhan ekonomi adalah investasi langsung luar negeri dan kredit domestik.

\section{DAFTAR PUSTAKA}

Alfaro, Laura. (2006). How Does Foreign Direct Investment Promote Economic Growth? Exploring the Effects of Financial Markets on Linkages. Harvard Business School.

Antwi, Samuel dan Xicang Zhao. (2013). Impact of Foreign Direct Investment and Economic Growth in Ghana: A Cointegration Analysis. International Business and Social Research. Vol 3, No. 1.

Boediono. (1985). Ekonomi Moneter. Yogyakarta: BPFE UGM Yogyakarta.

Boediono. (1989). Teori Pertumbuhan Ekonomi. Yogyakarta: BPFE UGM Yogyakarta.

Dewi, Diah Ananta. (2010). Tesis: Deindustrialisasi di Indonesia 1983-2008: Analisis Dengan Pendekatan Kaldorian. Bogor: Institut Pertanian Bogor.

Dumairy. (1999). Perekonomian Indonesia. Jakarta: Erlangga.

Enders W. (2004). Applied Econometrics Time Series. Second Edition. New York: John Wiley \& Son Inc.

Flexner, N. (2000). FDI and Economic Growth in Bolivia 1990-1998. Jornal Economic Policy Division Central Bank of Bolivia. La Paz, Bolivia.

Gujarati, Damodar N. (2003). Basic Econometrics. Fourth Edition. New York: McGraw-Hill Companiens.

Harahap, Mahindun Dhiani Melda. (2007). Tesis: Analisis Faktor-Faktor yang Mempengaruhi Utang Luar Negeri Indonesia. Medan: Universitas Sumatera Utara.

Juanda, Bambang dan Junaidi. (2012). Ekonometrika Deret Waktu: Teori dan Aplikasi. Bogor: IPB Press.

Kasmir. (2004). Bank Dan Lembaga Keuangan Lainnya. Jakarta: PT RajaGrafindo Persada.

Kaslan. (1970). Pengantar Ekonomi Tentang Uang - Kredit Bank. Jakarta: Gunung Agung.

Kutner, Michael H.; John Neter; William Wasserman. (1989). Applied Linear Regression Models. Second edition. United State of America: Library of Congress.

Krugman, Paul. (1999). Ekonomi Internasional: Teori dan Kebijakan [2 ${ }^{\text {nd }}$ edition]. Jakarta: PT Raja Grafindo Persada.

Majagaiya, Kundan P (2010). A Time Series Analysis of Foreign Direct Investment and Economic Growth: A Case Study of Nepal. International Journal of Business and Management. Vol.5 no, Februari 2010.

Mankiw, N. Gregory. (2003). Teori Makroekonomi Edisi 6 . Jakarta : Erlangga.

Moniruzzaman, M. D. (2011). The Export Supply Model of Bangladesh: An Application of Cointegration and Vector Error Correction Approaches. International Journal of Economics and Financial Issues. Vol. 1, No. 4, 163-171.

Nachrowi, Dajalal dan Hardius Usman. (2006). Pendekatan Populer dan Praktis Ekonometrika Untuk Analisis Ekonomi dan Keuangan. Depok : Lembaga Penerbit FE UI.

Nair-Reichert, Usha., Diana Weinhold. (1999). Causality Tests for Cross-Country Panels: New Look at FDI and Economic Growth in Developing Countries. Oxford Bulletin of Economics and Statistics Volume 63 Issue 2.

Nusantara, A. dan Astutik, E. P. (2001). Analisis Peranan Modal Asing Terhadap Pertumbuhan Ekonomi Indonesia. Jurnal Bisnis dan Ekonomi.

Raharja, Pratama dan Mandala Manurung. (2001). Teori Makro Ekonomi: Suatu Pengantar. Jakarta: LPFE Universitas Indonesia.

Republik Indonesia. (1998). Undang-Undang No. 10 Tahun 1998 tentang Perbankan. Lembaran Negara RI Tahun 1998. Jakarta: Sekretariat Negara.

Republik Indonesia. (2007). Undang-Undang No. 25 Tahun 2007 tentang Penanaman Modal. Lembaran Negara RI Tahun 2007, No. 67. Jakarta: Sekretariat Negara.

Rosidi A. (2004). Perlunya Analisis Data Deret Berkala (The Need for Time Series Analysis). Jakarta: Erlangga.

Rustiono, Deddy. (2008). Tesis: Analisis Pengaruh Investasi, Tenaga Kerja, Dan Pengeluaran Pemerintah Terhadap Pertumbuhan Ekonomi Di Propinsi Jawa Tengah. Semarang: Universitas Diponegoro.

Salvatore, Dominick. (2008). Theory and Problem of Micro Economic Theory. Third edition. New York: McGraw-Hill.

Setyowati dkk. (2008). Kausalitas Investasi Asing Terhadap Pertumbuhan Ekonomi: Error Correction Model. Jurnal Ekonomi dan Studi Pembangunan Volume 9, Nomor 1, April 2008: 69 - 88. 
Suryawati. (2000). Peranan Investasi Asing Langsung Terhadap Pertumbuhan Ekonomi di Negaranegara Asia Timur. Jurnal Ekonomi Pembangunan Kajian Negara Berkembang Vol. 5, No. 2, Hal. 101-113.

Todaro, M. P. dan Smith, S. C. (2003). Pembangunan Ekonomi di Dunia Ketiga. Munandar dan Puji [Penerjemah]. Jakarta: Erlangga.

Widowati , Diyah N. (2010). Tesisi: Analisis Pengaruh Penanaman Modal Asing Dan Utang Luar Negeri Terhadap Pertumbuhan Ekonomi Indonesia Periode Tahun 2000:1-2008:4. Surakarta : Universitas Sebelas Maret.

Zhang, Kevin Honglin. (2001). Does Foreign Direct Investment Promote Economic Growth? Evidence From East Asia And Latin America. Contemporary Economic Policy, April, 2001 Volume 19 Issue 2. 